\title{
Grow Tubes Change Microclimate and Bush Architecture but Have Little Effect on Bush Biomass Allocation at the End of the Establishment Year in Blueberry
}

\author{
Julie M. Tarara ${ }^{1}$ \\ USDA-ARS, Horticultural Crops Research Unit, 24106 N. Bunn Road, \\ Prosser, WA 99350 \\ Bernardo Chaves \\ Washington State University Irrigated Agriculture Research and Extension \\ Center, 24106 N. Bunn Road, Prosser, WA 99350
}

Bernadine C. Strik

Department of Horticulture, Oregon State University, Corvallis, OR 97330

Additional index words. mulch, radiation, temperature, tree shelter, Vaccinium corymbosum

Abstract. Microclimate variables were integrated over a 6-month period during which blueberry (Vaccinium corymbosum cv. Liberty) bushes were grown in $51-\mathrm{cm}$ high, 20-cm diameter round grow tubes (opaque or translucent) on a sawdust mulch-covered raised bed with the mulch incorporated into tilled soil. Grow tubes were installed around plants in the spring of 2006, 5 months after planting. Total photosynthetic photon flux $(P P F)$ density was $55 \%$ and $21 \%$ of ambient in translucent and opaque tubes, respectively. Daily maximum vapor pressure deficit consistently was highest in translucent tubes. Air $\left(T_{a}\right)$ and stem ( $\left.T_{\text {stem }}\right)$ temperatures in both grow tube types exceeded $T_{a}$ and $T_{\text {stem }}$ in nontubed plants (ambient). Maximum mulch surface temperature $\left(T_{m}\right)$ was lowest in opaque tubes, whereas there was no difference in $T_{m}$ between ambient and translucent tubes. The soil-mulch interface temperature $\left(T_{\mathrm{sm}}\right)$ was warmer outside tubes than $T_{\mathrm{sm}}$ inside tubes. Soil temperatures directly under the tubes differed very little between tube types and ambient, generally less than $1^{\circ} \mathrm{C}$. Root and crown dry mass (DM) did not differ between tubed plants and ambient at the end of the establishment year. Leaf area, leaf DM, and fruit bud number were suppressed inside tubes. All plants were greater than $51 \mathrm{~cm}$ tall at the end of the growing season. Substantial compensatory growth occurred above tubes: tubed plants were more upright and had more leaf area, leaf DM, and shoot growth than ambient plants above $51 \mathrm{~cm}$. However, there was no difference between tubed and ambient plants in fruit bud number, total plant leaf area, shoot:root, or DM of 1- and 2year-old wood. Grow tubes can alter microclimate and architecture of young blueberry bushes but have no significant influence on size and distribution of total DM after one growing season in the field.

Grow tubes have garnered attention in horticulture, most notably in grape (Hall and Mahaffee, 2001; Munnell, 2003). However, their use is not described extensively in the horticultural literature (e.g., Due, 1990; Kjelgren, 1994; Kjelgren et al., 1997; Tarara et al., 2013). Grow tubes were first used in

Received for publication 23 Jan. 2014. Accepted for publication 18 Mar. 2014.

We appreciate the research support provided by the Oregon Blueberry Commission and the valuable contributions of our grower collaborator (PanAmerican Berry Growers, Salem, OR).

Mention of trade names or commercial products in this article is solely for the purpose of providing specific information and does not imply recommendation or endorsement by the U.S. Department of Agriculture.

${ }^{1}$ To whom reprint requests should be addressed; e-mail julie.tarara@ars.usda.gov.
In horticulture, grow tubes generally are used during one growing season but occasionally are left in place over the winter to protect the plants from any initial herbicide application the next spring. Tubes that are used in crops like grape generally are unventilated and are made from opaque or translucent materials. The primary purposes of using grow tubes over grapevines are to accelerate shoot growth, minimize herbicide damage, reduce disease incidence (Hall and Mahaffee, 2001), and protect new transplants from high winds. Tube bases often are pushed into the soil to reduce tube displacement or damage from high wind, thereby minimizing maintenance costs.

There is interest in using grow tubes to improve establishment of highbush blueberry (Vaccimium corymbosum L.). Grow tubes may be advantageous by promoting vegetative growth in addition to protecting the young bushes from wind and herbicides. It is not known how the microclimate within grow tubes may influence either above- or below-ground growth or bush architecture. Information about how grow tubes influence plant growth and microclimate from grape and forest applications may not be applicable to blueberry growing systems. Highbush blueberries are grown commercially in an organic mulch-incorporated bed, and the bed is covered with the same mulch. Thus, the blueberry plant's crown and root system is established in three strata: mulch, mulchincorporated soil, and tilled native soil. In vineyard and afforestation systems, plants typically are established in disturbed mineral soils with no amendments or mulch. In addition, growth of renewal wood ("whips") in blueberry originates from the crown or plant base. In comparison, the preferred growth habit of grapevines and forest trees is a single trunk. Differences in growing substrate and plant growth habit may affect substantially how grow tubes alter the microclimate and plant growth.

Recently we characterized above- and below-ground temperatures in a blueberry field in which unventilated single-wall grow tubes (translucent, opaque) were installed for the establishment year (first growing season after field planting; Tarara et al., 2013). We report the extent to which unventilated grow tubes influence above- and below-ground growth and canopy architecture (plant height and canopy diameter) of the blueberry bushes at the end of the establishment year. The objectives of this study were to: 1) compare the distribution of total plant growth among tissues, segregating that inside the tube from that above the top of the tube; and 2) determine whether seasonal representations of tube microclimate (temperature, solar radiation, humidity) could account for any differences in plant growth resulting from grow tubes.

\section{Materials and Methods}

Kjelgren et al., 1997; Mayhead and Boothman, 1997) and sometimes at the expense of root growth (e.g., Burger et al., 1992; Coutand et al., 2008; Mayhead and Boothman, 1997; Sharpe et al., 1999). 
(2013). A summary of the methods given in Tarara et al. (2013) is given below with more details that pertain to the measurement of plant variables, seasonal integration of microclimate data, and data analyses.

Field site. The study was conducted in a commercial blueberry field near Salem, OR (lat. $45^{\circ} 00^{\prime} 59^{\prime \prime} \mathrm{N}$, long. $122^{\circ} 56^{\prime} 36^{\prime \prime} \mathrm{W}$ ) on a tilled Woodburn silt loam formed into trapezoidal raised beds $(3.05 \mathrm{~m}$ apart on center) with a base width of $\approx 120 \mathrm{~cm}$, a top width of $\approx 55 \mathrm{~cm}$, and total height of $\approx 25$ $\mathrm{cm}$. Douglas-fir (Pseudotsuga menziesii) sawdust $(91 \%$ of particles less than $4 \mathrm{~mm}$ ) was incorporated into the top $15 \mathrm{~cm}$ of the bed before planting. In the fall of 2005, commercial stock (18-month-old, 3.8-L container-grown) of northern highbush blueberry, cv. Liberty, with two to four whips each (whip diameter 4 to $7 \mathrm{~mm}$ ) were planted in the center of the row $(0.75 \mathrm{~m}$ apart). Sawdust mulch was drop-spread on top of the bed to a depth of $\approx 5 \mathrm{~cm}$. Amending the soil with sawdust before planting is a standard practice for commercial blueberry production in the Pacific Northwest (Julian et al., 2011). Because all plants were grown under identical production practices during the establishment year (other than the grow tube), the use of an amendment would not have affected response to treatment. The longer-term impacts of tubes on plant architecture are described by Strik et al. (2014).

On day of year (DOY) 100, 2006, one of two unventilated, single-wall grow tubes $(51 \mathrm{~cm}$ high, $20 \mathrm{~cm}$ diameter) was installed over the plants: white translucent (Blehyl Farm Service, Grandview, WA) or beige opaque (Wilson Orchard and Vineyard Supply, Yakima, WA). The bottom edge of the tube was pushed into the bed. Tubes were held in place by two vertical bamboo stakes. There were three plants in each of the two tube types [opaque (OP); translucent (TR)] and three control or ambient plants with no tubes installed (NT). The planting otherwise was managed using standard practices for blueberry production in Oregon (Strik et al., 1993).

Microclimate measurements. PPF density $(P P F D)$ was measured by a silicon quantum sensor (LI-190; LI-COR, Lincoln, NE) at 25 $\mathrm{cm}$ above ground in one empty tube per tube type and at a similar location to represent $P P F D$ for NT plants (Tarara et al., 2013). Air temperature and relative humidity $(\mathrm{RH})$ at midtube height ( $25 \mathrm{~cm}$ above the bed surface) were measured on three plants per treatment in a completely randomized design. We used custom-built T/RH sensors (Center for Precision Agricultural Systems, Washington State University, Prosser, WA; Tarara et al., 2013). Saturation vapor pressure was computed from $T_{a}$ using Murray's equation (Murray, 1967). Vapor pressure deficit (VPD) was computed from the difference between saturated and actual vapor pressure at $\mathrm{T}_{\mathrm{a}}$. Other meteorological variables (global irradiance, wind speed) were measured at a reference height of $2 \mathrm{~m}$ above ground (Tarara et al., 2013).
Temperatures of stems $\left(\mathrm{T}_{\text {stem }}\right)$, the mulch surface $\left(\mathrm{T}_{\text {mulch }}\right)$, the mulch-bed interface $\left(\mathrm{T}_{\mathrm{sm}}\right)$, and the soil beneath the mulch $\left(\mathrm{T}_{\text {soil }}\right)$ were measured by Type $\mathrm{T}$ thermocouples (copper-constantan) with three junctions wired in parallel for each measurement (Tarara et al., 2013). The $\mathrm{T}_{\text {stem }}$ was measured at midtube height on three whips per plant, on the north aspect of the whips, by inserting junctions just beneath the bark surface in a small slit and securing the wire with grafting tape. Mulch surface temperature was measured with sawdust-encapsulated thermocouples. The $\mathrm{T}_{\mathrm{sm}}$ was measured in the soil immediately below the mulch, and $\mathrm{T}_{\text {soil }}$ was measured at $15 \mathrm{~cm}$ below the soil-mulch interface.

Signals from all sensors in the experiment were scanned every $5 \mathrm{~s}$ and averaged every 12 min by a multiplexed data logger system (AM-416 and CR-10X; Campbell Scientific, Logan, UT) from DOY 110 to DOY 293, 2006. The PPFD was summed by day $\left(\mathrm{mol} \cdot \mathrm{m}^{-2} \cdot \mathrm{d}^{-1}\right)$ and for the entire experiment $\left(\mathrm{mol} \cdot \mathrm{m}^{-2}\right)$. Daily maximum and minimum temperatures $\left(T_{a}, T_{\text {stem }}, T_{\text {mulch }}, T_{\text {sm }}, T_{\text {soil }}\right)$ were computed and then integrated by the trapezoidal method to obtain a total seasonal value (area under each curve). Temperatures also were expressed as thermal time in degree-days with a base of $10^{\circ} \mathrm{C}$ (Bryla et al., 2009; Hall et al., 1979); 10 to $30^{\circ} \mathrm{C}$, the range of temperature purported to represent blueberry growth (Hancock et al., 1992; Moon et al., 1987); and the total number of hours during the experiment that the temperature variable exceeded high-temperature thresholds of 30 and $40{ }^{\circ} \mathrm{C}$. Vapor pressure approached saturation on most nights, both inside and outside the tubes. Therefore, only the maximum daily VPD was computed and integrated to obtain a seasonal value. The daily amplitudes of temperature and VPD were computed and integrated.

Plant growth and architecture. All plants were harvested on DOY 294. Plants were rated for upright or prostrate growth habit on a scale of 1 to 5 where 1 represented a prostrate plant and 5 a maximally upright plant. The plane area projected by the canopy was estimated by measuring in orthogonal directions the maximum diameter of the canopy. Total plant height and that above the tube were measured to the nearest $1 \mathrm{~cm}$. Plants were excavated from the soil and mulch by hand using shovels. Soil was removed from the root system using a highpressure hose and tap water. The aboveground structures of each plant were separated into above and below the top of the grow tube. Plants were divided into the following components: leaves, roots, crown, 2-year-old wood, 1-year-old wood (originating from 2year-old wood excluding whips), and whips (shoots arising from the base of the bush, often from older wood). Leaf area was measured by area meter (LI-3100 leaf area meter; LI-COR). Specific leaf area (SLA) was calculated as leaf area per unit dry mass. Fruit buds on 1-year-old wood were counted. The diameter of the current season's whips (renewal wood) was measured to the nearest $1 \mathrm{~mm}$ using a caliper. The diameter of 1 -yearold wood was not measured. Plant parts were dried to constant mass $(\approx 3 \mathrm{~d})$ at $60{ }^{\circ} \mathrm{C}$ using a dryer oven (Fisher Scientific Isotemp oven Model 655F, Montreal, Quebec, Canada) and dry mass was measured to the nearest $1 \mathrm{~g}$. Total plant values were computed by summing the sectioned values.

Data analyses. Data were post-processed using SAS (Version 9.3; SAS Institute, Cary, $\mathrm{NC}$ ) and mean values of the three replicates are presented. Analysis of variance (ANOVA) and contrasts were used to assess treatment differences in micrometeorological and plant variables at $P<0.05$. Residuals were tested for normality using the Shapiro-Wilk test and for homogeneity of variance with Levene's test. Where necessary, data were transformed to meet criteria for normality and homogeneity of variance. Transformed variables were used in the ANOVA and contrasts, and data were back-transformed to compute means and SES. Relationships among micrometeorological variables and relationships between micrometeorological variables and plant variables were evaluated using the Spearman rank correlation coefficient $(r)$ at $P<0.05$.

\section{Results and Discussion}

Micrometeorological variables. Total seasonal $P P F D$ in a TR tube $\left(3360 \mathrm{~mol} \cdot \mathrm{m}^{-2}\right)$ was $55 \%$ of ambient $\left(6107 \mathrm{~mol} \cdot \mathrm{m}^{-2}\right) ; P P F D$ in an OP tube $\left(1290 \mathrm{~mol} \cdot \mathrm{m}^{-2}\right)$ was $21 \%$ of ambient and $38 \%$ of that in TR. At times, daily maximum PPFD inside the tubes was higher than ambient (Tarara et al., 2013), indicating multiple reflections of direct irradiance along the inner wall of the tube. Once the plant canopy shaded the top of the tube, this phenomenon would not have occurred because all solar radiation would have entered the tube through its walls. However, the diameter of the tubes had precluded us from using radiation sensors conjointly in tubes with plants. Thus, for the grow tubes, total $P P F D$ reported here is higher than actual for the period after the canopy had grown above $51 \mathrm{~cm}$ and had obscured the tube opening. Nonetheless, the measured $P P F D$ provides a practical surrogate for comparing treatments. After the canopy had grown above the top of the tube, the in situ transmissivity of the installed tube would have approached the nominal transmissivity of the material. In OP, the nominal transmissivity was $0.1 \%$ in the visible waveband ( 400 to $700 \mathrm{~nm}$ ) and in TR, it was $21.2 \%$ (Tarara et al., 2013), indicating that tissues inside the tubes were subjected to very low solar radiation for much of the establishment year. Therefore, one would expect them to have been shade acclimated, which in general is associated with lower rates of photosynthesis per unit leaf area (Jones, 2014).

When integrated over the season as daily maxima, VPD was highest in TR and lowest outside the tubes (Table 1), concurring with patterns observed by Bellot et al. (2002) using translucent tubes over an oak shrub (Quercus coccifera). Integrated minimum 
VPD did not differ among treatments because saturation vapor pressure was approached on most nights (data not shown), as also observed by Bellot et al. (2002). A mean maximum VPD was $3.87 \mathrm{kPa}$ in TR, $2.79 \mathrm{kPa}$ in OP, and $1.87 \mathrm{kPa}$ for NT. The VPD differences are a function of air temperature because values of actual vapor pressure did not differ among treatments (data not shown). Elsewhere in blueberry (Moon et al., 1987), in response to a change in VPD from 1 to $3 \mathrm{kPa}$, there was a $56 \%$ to $60 \%$ reduction in leaf conductance to water vapor but an increase in transpiration. In contrast to our plants, those of Moon et al. (1987) were not sheltered and thus were subjected to a low boundary layer resistance to vapor transport. In grow tubes, the boundary layer resistance is large. Therefore, despite their observation, it is reasonable to suspect low transpiration inside tubes. Bergez and Dupraz (2000) found lower rates of transpiration inside tubes than under ambient conditions (Prunus avium), as did Kjelgren and Rupp (1997; Acer platanoides and Fraxinus pennsylvanica).

A number of approaches can be taken to summarize temperature across a season such that associated responses in plant growth can be inferred. We computed four temperature summaries: 1) integrated daily maxima for exposure to high temperatures; 2) integrated daily minima for night temperatures; 3 ) thermal time as a summary of temperature means; and 4) the duration between 10 and $30^{\circ} \mathrm{C}$ as a range between the presumed base temperature for growth in blueberry (Bryla et al., 2009; Hall et al., 1979) and the temperature at which net photosynthesis has been shown to decline markedly in highbush cultivars (Hancock et al., 1992; Moon et al., 1987). For example, in 'Bluecrop' and 'Elliott', a parent of 'Liberty', photosynthesis decreased by $24 \%$ to $27 \%$ when $\mathrm{T}_{\mathrm{a}}$ increased from 20 to $30{ }^{\circ} \mathrm{C}$ (Hancock et al., 1992). Henceforth, we refer to this last temperature variable as the biologically active range $\left(\mathrm{T}_{\text {bio }}\right)$.

Integrated across the season, daily maximum and minimum $\mathrm{T}_{\mathrm{a}}, \mathrm{T}_{\mathrm{a}}$ expressed as thermal time, and $\mathrm{T}_{\mathrm{a}}$,bio were significantly different among treatments (Table 1). Ambient $T_{a}$ was lower than that in either tube during the day and slightly higher at night. Integrated daily minimum (nighttime) $\mathrm{T}_{\mathrm{a}}$ in the tubes was $10 \%$ to $13 \%$ lower than ambient. These results differ to some extent from those of Ogden and van Iersel (2009) where in blueberries under closed high tunnels in winter, minimum $\mathrm{T}_{\mathrm{a}}$ inside the tunnels did not differ from ambient. Their maximum $\mathrm{T}_{\mathrm{a}}$ reflected the differences that we observed in grow tubes: the integrated maximum for TR was $45 \%$ higher than NT and $14.5 \%$ higher than OP. The less extreme temperatures $\left(\mathrm{T}_{\text {bio }}\right)$ were more prevalent at ambient $\mathrm{T}_{\mathrm{a}}$ than inside either tube.

Stem temperatures were positively correlated with $\mathrm{T}_{\mathrm{a}}$ if expressed as an integrated daily maximum $(r=0.933, P=0.0002)$, as thermal time $(r=0.833, P=0.005)$, or as $\mathrm{T}_{\text {bio }}$ $(r=0.90, P=0.0009)$. The highest $\mathrm{T}_{\text {stem }}$, like $\mathrm{T}_{\mathrm{a}}$, were in TR. Overall, minimum $\mathrm{T}_{\text {stem }}$ was slightly lower than $\mathrm{T}_{\mathrm{a}}$ in all treatments, indicating a small amount of convective and radiative heat transfer from the stems of NT, and radiative transfer between TR and OP stems, and the tube walls. Boundary layer resistance to heat and mass transport is an inverse function of wind speed. The low rates of air exchange and concomitant high boundary layer resistance in a solid-walled tube (Bergez and Dupraz, 1997, 2000) mean that convective heat transfer in the tubes was only by the less effective free convection, where mixing lengths are on the order of the tube diameter (Baird and Legree, 1994; $20 \mathrm{~cm}$ or $\approx 40 \%$ of tube height in our case).

The duration of which $\mathrm{T}_{\text {mulch }}$ in NT exceeded $40{ }^{\circ} \mathrm{C}$ was significantly higher than in either tube $(P<0.001$; data not shown); it constituted $7.7 \%$ of the duration of the experiment (NT), $5.0 \%$ in TR, and $0.2 \%$ in OP. However, integrated across the season, daily maximum ambient $T_{\text {mulch }}$ was not significantly different from TR (Table 1) because of convective heat transfer away from the mulch surface outside the tubes on windy days and little difference between NT and TR under overcast skies. The integrated maximum value of $\mathrm{T}_{\text {mulch }}$ for OP was significantly lower than either NT (by 27\%) or TR (by $23 \%$ ). Mulch surface temperature differed among treatments when expressed as $\mathrm{T}_{\text {bio }}$ with the most moderate temperatures in OP. At night (integrated daily minimum $\mathrm{T}_{\text {mulch }}$ ), NT was lower than either tube, indicating more heat transfer away from the exposed surface.

Expressed as $\mathrm{T}_{\text {bio, }}$, there were no significant differences in $\mathrm{T}_{\mathrm{sm}}$ among treatments. Integrated daily maximum $\mathrm{T}_{\mathrm{sm}}$, like $\mathrm{T}_{\text {mulch }}$, was highest in NT, reflecting the more

Table 1. Contrasts of seasonal summary of vapor pressure deficit (VPD) and temperature variables above- and below-ground inside two grow tubes: white translucent (TR) and beige opaque (OP), and for ambient conditions [no tube (NT)]. ${ }^{\mathrm{z}}$

\begin{tabular}{|c|c|c|c|c|c|c|c|c|}
\hline \multirow[b]{2}{*}{ Summary method } & \multirow[b]{2}{*}{ Variable } & \multicolumn{3}{|c|}{ Treatment } & \multicolumn{4}{|c|}{ Contrast $P$ values } \\
\hline & & NT & TR & OP & NT vs. tube & NT vs. TR & NT vs. OP & OP vs. TR \\
\hline Integrated daily maximum VPD (kPa) & VPD & $342(1.5)$ & $708(32.6)$ & $511(18.9)$ & 0.001 & $<0.001$ & 0.0015 & 0.007 \\
\hline \multirow[t]{5}{*}{ Integrated daily maximum temperature $\left({ }^{\circ} \mathrm{C}\right)$} & $\operatorname{Air}^{y}$ & $3823(11.6)$ & $5543(47.9)$ & $4737(59.1)$ & $<0.001$ & $<0.001$ & $<0.001$ & $<0.001$ \\
\hline & Stem $^{y}$ & $4223(41.6)$ & $5092(64.7)$ & $4511(41.9)$ & $<0.001$ & $<0.001$ & 0.0069 & 0.0002 \\
\hline & $\operatorname{Mulch}^{\mathrm{x}}$ & $5889(83.1)$ & $5560(150.4)$ & $4286(32.0)$ & 0.002 & $\mathrm{NS}^{\mathrm{u}}$ & $<0.001$ & 0.0069 \\
\hline & Soil-mulch ${ }^{\mathrm{w}}$ & $3512(43.6)$ & $3325(47.9)$ & $3250(37.7)$ & 0.005 & 0.022 & 0.005 & NS \\
\hline & Soil $^{\mathrm{v}}$ & $3077(2.3)$ & $3009(10.5)$ & $2991(4.8)$ & $<0.001$ & $<0.001$ & $<0.001$ & NS \\
\hline \multirow[t]{5}{*}{ Integrated daily minimum temperature $\left({ }^{\circ} \mathrm{C}\right)$} & Air & $1152(4.0)$ & $1006(4.8)$ & $1035(6.1)$ & $<0.001$ & $<0.001$ & $<0.001$ & 0.007 \\
\hline & Stem & $1079(6.6)$ & $972(3.9)$ & $1021(6.8)$ & $<0.001$ & $<0.001$ & $<0.001$ & 0.001 \\
\hline & Mulch & $1137(34.6)$ & $1279(46.5)$ & $1311(18.0)$ & 0.011 & 0.029 & 0.013 & NS \\
\hline & Soil-mulch & $2311(58.5)$ & $2323(56.9)$ & $2269(56.9)$ & NS & NS & NS & NS \\
\hline & Soil & $2759(11.4)$ & $2742(6.5)$ & $2742(19.7)$ & NS & NS & NS & NS \\
\hline \multirow[t]{5}{*}{ Thermal time (degree-days, ${ }^{\circ} \mathrm{C}$ ) } & Air & $1073(3.6)$ & $1797(25.9)$ & $1472(16.5)$ & $<0.001$ & $<0.001$ & $<0.001$ & $<0.001$ \\
\hline & Stem & $1187(6.0)$ & $1491(12.6)$ & $1338(17.2)$ & $<0.001$ & $<0.001$ & $<0.001$ & $<0.001$ \\
\hline & Mulch & $1682(20.9)$ & $1699(38.4)$ & $1264(1.2)$ & $<0.001$ & NS & $<0.001$ & $<0.001$ \\
\hline & Soil-mulch & $1425(9.8)$ & $1342(13.7)$ & $1270(20.0)$ & $<0.001$ & 0.008 & $<0.001$ & 0.015 \\
\hline & Soil & $1474(0.6)$ & $1424(12.6)$ & $1414(9.5)$ & $<0.001$ & 0.003 & 0.001 & NS \\
\hline \multirow[t]{5}{*}{ Duration between 10 and $30^{\circ} \mathrm{C}(\mathrm{h})$} & Air & $2800(6.0)$ & $1798(22.2)$ & $2257(25.0)$ & $<0.001$ & $<0.001$ & $<0.001$ & $<0.001$ \\
\hline & Stem & $2615(18.4)$ & $2061(73.6)$ & $2404(30.9)$ & $<0.001$ & $<0.001$ & 0.020 & 0.002 \\
\hline & Mulch & $2179(25.4)$ & $2291(45.6)$ & $2794(15.1)$ & $<0.001$ & 0.046 & $<0.001$ & $<0.001$ \\
\hline & Soil-mulch & $3572(18.2)$ & $3619(26.8)$ & $3597(18.2)$ & NS & NS & NS & NS \\
\hline & Soil & $3708(1.0)$ & $3709(0)$ & $3709(0)$ & NS & NS & NS & NS \\
\hline
\end{tabular}

${ }^{\mathrm{z}}$ Numbers in parentheses are SES of the mean.

${ }^{\mathrm{y}}$ Air and 1-year-old stem temperatures were measured at $25 \mathrm{~cm}$ above ground.

${ }^{\mathrm{x}}$ Surface temperature of $5-\mathrm{cm}$ deep sawdust mulch.

wTemperature at the interface between the sawdust mulch and the mulch-incorporated soil that comprised the raised bed

vemperature of the native soil at $15 \mathrm{~cm}$ below the soil-mulch interface.

${ }^{\mathrm{u}_{\mathrm{NS}}}=$ Nonsignificant at $P<0.05$. 
frequent extreme temperatures in the dry mulch particles (Table 1). The daily amplitude of $\mathrm{T}_{\mathrm{sm}}$ was lower than that of $\mathrm{T}_{\text {mulch }}$ whether inside or outside of a tube (data not shown). The $\mathrm{T}_{\mathrm{sm}}$ was strongly correlated with $\mathrm{T}_{\text {mulch }}$ only when the two were expressed as integrated daily maxima $(r=0.933, P<$ 0.001). Among all temperature variables, the largest gradients, or driving force for heat transfer, were between $T_{\text {mulch }}$ and $T_{\text {sm }}$, but only under extremely high $\mathrm{T}_{\text {mulch. }}$ On the whole, there would have been limited conduction from the surface of the loose, dropspread mulch to the subsurface, unlike in systems with high mulch-surface contact (Tarara and Ham, 1999); this would have been the case for all treatments.

Ogden and van Iersel (2009) observed daily maximum soil temperature $(10 \mathrm{~cm}$ deep) differences of 5 to $7^{\circ} \mathrm{C}$ in closed high tunnels (tunnel $>$ ambient). By contrast in our grow tubes, instantaneous differences in $\mathrm{T}_{\text {soil }}$ at $15 \mathrm{~cm}$ were on the order of less than $1{ }^{\circ} \mathrm{C}$ (Tarara et al., 2013). Although seasonal summaries of these values differed statistically among treatments (Table 1), the magnitude of the differences was not meaningful for root growth (DM). We did not observe differences in root DM between NT and either tube or between tubes (Table 2). Abbott and Gough (1987) found that for blueberry plants grown on flat ground, an optimal temperature range for the growth of new unsuberized roots was between 14 and $18{ }^{\circ} \mathrm{C}$ in a 15 -cm-deep sawdust mulch. On raised beds identical to ours (Bryla and Strik, 2007), most of a 5-year-old blueberry bush's root system was between the soil surface and $25 \mathrm{~cm}$. In the present study, $\mathrm{T}_{\text {soil }}$ at $15 \mathrm{~cm}$ was below $20{ }^{\circ} \mathrm{C}$ for $\approx 60 \%$ of the experiment's duration in all treatments; it never exceeded $30{ }^{\circ} \mathrm{C}$. By contrast, temperature at the soil-mulch interface, which could affect the roots and the crown, was less than $20{ }^{\circ} \mathrm{C}$ for $35 \%$ of the experiment in NT, $32 \%$ in TR, and $28 \%$ in OP (data not shown). The $\mathrm{T}_{\text {sm }}$ was above $30{ }^{\circ} \mathrm{C}$ for $13.2 \%(\mathrm{NT}), 5.1 \%(\mathrm{OP})$, and $3.5 \%$ (TR) of the season, respectively, but never exceeded $40{ }^{\circ} \mathrm{C}$. A temperature optimum for crown growth is not known nor is a threshold temperature that is detrimental to crown growth. As with root dry mass, we did not find differences in crown dry mass between NT and either tube or between tubes (Table 2).

It has been shown elsewhere (Larco et al., 2013) that blueberry growth does respond to surface and near-surface temperatures. Black weed mat, which with its low albedo can induce very high surface and near-surface temperatures, was associated with less root and crown growth but more top growth of blueberry during establishment. In the same study, sawdust mulches, with more moderate temperatures compared with black weed mat, induced more whip growth than did the weed mat.

Plant variables. Below the top of the tube (i.e., less than $51 \mathrm{~cm}$ ), the NT bushes had $67 \%$ more leaf area than TR and 2.5 times more than OP, a radiation effect. The two tubes did not differ significantly from one another (Table 2). Conversely, in the shrub Quercus coccifera (Bellot et al., 2002) that did not grow above a $30-\mathrm{cm}$ tall tube, no differences in total leaf area were found between the tubed seedlings and non-tubed seedlings. Specific leaf area below the tops of our tubes was highest in OP, intermediate in $\mathrm{TR}$, and lowest in NT, also indicative of a radiation or shade effect more than a response to temperature. Specific leaf area was indeed significantly associated with $P P F D$ (Table 3) as were leaf area and leaf DM, DM of 1-year-old wood, and number of fruiting buds below the top of the tube. In general, SLA is known to increase in response to shade (e.g., Grace, 1983; Nobel, 1999) and this has been shown in blueberry under shade netting (Lobos et al., 2012). Whip diameter below $51 \mathrm{~cm}$ did not differ among treatments, in keeping with findings of Bellot et al. (2002; Quercus coccifera) but contrary to findings with Ficus benjamina (Scuderi et al., 2012) where stem diameter decreased linearly with degree of whole-plant shading. We did not observe significant differences in the number of whips despite other work indicating that shading (Kim et al., 2011) or opaque grow tubes (Strik et al., 2014) reduced the number of whips per plant.

For substantial portions of the day inside TR tubes and continuously in OP, PPFD would have been well below an approximate light saturation level for photosynthesis as has been estimated in two other northern highbush cultivars: 'Bluecrop' [600 to 700 $\mu \mathrm{mol} \cdot \mathrm{m}^{-2} \cdot \mathrm{s}^{-1}$ (Rho et al., 2012); and 700 to $900 \mu \mathrm{mol} \cdot \mathrm{m}^{-2} \cdot \mathrm{s}^{-1}$ (Moon et al., 1987)] and 'Jersey' (600 to $800 \mu \mathrm{mol} \cdot \mathrm{m}^{-2} \cdot \mathrm{s}^{-1}$; Moon et al., 1987). Furthermore, photosynthesis may have been suppressed by high concentrations of $\mathrm{CO}_{2}$ in the tubes (Dupraz and Bergez, 1999) driven by high boundary layer resistance to gas flux. Early in the season this would have been disadvantageous because it may have compromised crown and root growth, sources of carbohydrate for whip initiation, and shoot and leaf growth (Strik et al., 2014). Later, when shoots were growing above the tube, the crown and roots may have been significant sinks. At the end of the establishment year, we did not find differences in crown or root dry matter among treatments (Table 2) in contrast to what was found in another study on blueberry (Strik et al., 2014). We found that plants in grow tubes produced much more top growth (above $51 \mathrm{~cm}$ ) than those without tubes (Table 4), likely increasing the carbon source potential for some portion of the year.

Below the top of the tube, $\mathrm{T}_{\mathrm{sm}}$ was associated with leaf-related measures plus the number of whips, which emerge from the plant base (Table 3). Between the two tubes, there were more whips in TR than in OP (Table 2), likely a radiation and temperature response. Radiation incident on the crown has been found to increase primocane number in blackberry (Strik et al., 2012; Swartz et al., 1984), but a relationship between near-surface temperature and primocane initiation in blackberry is not known.

The differences in the number of fruiting buds below the top of the tube were more dramatic than were growth indicators, where NT bushes had 6-fold more fruiting buds than TR and 10-fold more than OP. Shading has been shown to reduce fruit bud number (Retamales and Hancock, 2012; Yáñez et al., 2009 ). Under $75 \%$ to $80 \%$ shade, there were significantly fewer fruiting buds per cane than under $\approx 30 \%$ or $\approx 60 \%$ shade (Lobos et al., 2013). Within a cultivar, the number of fruiting buds is positively correlated with shoot diameter and incident solar radiation (Retamales and Hancock, 2012; Yáñez et al., 2009). With respect to the initiation of fruiting

Table 2. Contrasts of blueberry bush tissues below the top $(51 \mathrm{~cm})$ of two grow tubes-white translucent (TR) and beige opaque (OP), and under ambient conditions [no tube (NT)], at the end of the establishment year. ${ }^{2}$

\begin{tabular}{|c|c|c|c|c|c|c|c|}
\hline \multirow[b]{2}{*}{ Variable } & \multicolumn{3}{|c|}{ Treatment means } & \multicolumn{4}{|c|}{ Contrast $P$ values } \\
\hline & NT & TR & OP & NT vs. Tube & NT vs. TR & NT vs. OP & OP vs. TR \\
\hline Leaf area $\left(\mathrm{cm}^{2}\right)$ & $4244(923.7)$ & $2516(280.0)$ & $1208(126.9)$ & 0.013 & $\mathrm{NS}^{\mathrm{y}}$ & 0.009 & NS \\
\hline Fruiting bud number & $59.0(1.73)$ & $8.3(0.33)$ & $5.3(0.67)$ & $<0.001$ & $<0.001$ & $<0.001$ & NS \\
\hline Whip number & $9.3(0.67)$ & $11.3(2.33)$ & $5.7(0.67)$ & NS & NS & NS & 0.033 \\
\hline Whip diameter (mm) & $6.0(0.38)$ & $5.6(0.16)$ & $5.6(0.29)$ & NS & NS & NS & NS \\
\hline Root dry matter (g) & $52.7(13.30)$ & $63.0(5.29$ & $52.3(12.25)$ & NS & NS & NS & NS \\
\hline Crown dry matter $(\mathrm{g})$ & $36.0(1.00)$ & $36.7(3.71)$ & $29.0(6.24)$ & NS & NS & NS & NS \\
\hline Two-year-old wood dry matter (g) & $23.0(1.53)$ & $22.3(1.76)$ & $37.0(8.50)$ & NS & NS & NS & NS \\
\hline One-year-old wood dry matter (g) & $70.7(12.91)$ & $71.7(11.92)$ & $37.3(6.64)$ & NS & NS & NS & NS \\
\hline Leaf dry matter $(\mathrm{g})$ & $51.0(10.82)$ & $22.3(1.86)$ & $7.0(1.00)$ & 0.0035 & NS & 0.019 & 0.0027 \\
\hline Specific leaf area $\left(\mathrm{cm}^{2} \cdot \mathrm{g}^{-1}\right)$ & $83.0(1.42)$ & $112.2(3.74)$ & $175.0(8.95)$ & 0.0001 & 0.011 & $<0.0001$ & 0.0002 \\
\hline Dry matter below $51 \mathrm{~cm}(\mathrm{~g})$ & $233.3(38.74)$ & $216.0(19.01)$ & $162.7(33.34)$ & NS & NS & NS & NS \\
\hline
\end{tabular}

${ }^{\mathrm{z}}$ Numbers in parentheses are SES of the mean.

${ }^{\mathrm{y}_{\mathrm{NS}}}=$ Nonsignificant at $P<0.05$. 


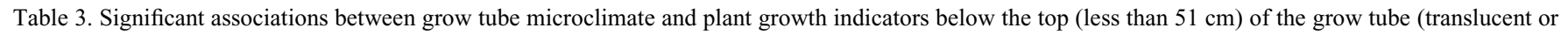
opaque) at the end of the establishment year in blueberry. ${ }^{\mathrm{z}}$

\begin{tabular}{|c|c|c|c|c|c|c|c|}
\hline & & \multicolumn{6}{|c|}{ Plant variable at end of establishment year } \\
\hline & & $\begin{array}{c}\text { Leaf } \\
\text { area }\left(\mathrm{cm}^{2}\right)\end{array}$ & $\begin{array}{l}\text { Number } \\
\text { of buds }\end{array}$ & $\begin{array}{l}\text { Number } \\
\text { of whips }\end{array}$ & $\begin{array}{c}\text { One-year-old } \\
\text { wood dry matter }(\mathrm{g})\end{array}$ & $\begin{array}{l}\text { Leaf dry } \\
\text { matter }(\mathrm{g})\end{array}$ & $\begin{array}{l}\text { Specific leaf } \\
\text { area }\left(\mathrm{cm}^{2} \cdot \mathrm{g}^{-1}\right)\end{array}$ \\
\hline \multicolumn{8}{|l|}{ Microclimate variable } \\
\hline \multirow[t]{2}{*}{ Integrated daily maximum $\mathrm{T}_{\mathrm{sm}^{\mathrm{y}}}^{\mathrm{y}}$} & $r$ & 0.883 & 0.882 & 0.734 & 0.733 & 0.895 & -0.767 \\
\hline & $P$ value & 0.002 & 0.002 & 0.024 & 0.025 & 0.001 & 0.016 \\
\hline \multirow[t]{2}{*}{ Integrated daily maximum $T_{\text {mulch }}{ }^{x}$} & $r$ & 0.917 & 0.908 & . & 0.833 & 0.929 & -0.783 \\
\hline & $P$ value & 0.0005 & 0.0007 & $\mathrm{NS}^{\mathrm{w}}$ & 0.0053 & 0.0003 & 0.0125 \\
\hline \multirow[t]{2}{*}{ Total $P P F D^{\mathrm{v}}\left(\mathrm{mol} \cdot \mathrm{m}^{-2}\right)$} & $r$ & 0.900 & 0.957 & . & 0.685 & 0.953 & -0.949 \\
\hline & $P$ value & 0.001 & $<0.0001$ & NS & 0.042 & $<0.0001$ & $<0.0001$ \\
\hline
\end{tabular}

${ }^{\mathrm{z}}$ Correlation coefficients are Spearman rank $(r)$.

${ }^{\mathrm{y}} \mathrm{T}_{\mathrm{sm}}=$ Temperature $\left({ }^{\circ} \mathrm{C}\right)$ at the soil-mulch interface, $\approx 5 \mathrm{~cm}$ below the surface.

${ }^{\mathrm{x}} \mathrm{T}_{\text {mulch }}=$ Temperature $\left({ }^{\circ} \mathrm{C}\right)$ at the sawdust-mulch surface.

$\mathrm{w}_{\mathrm{NS}}=$ Nonsignificant at $P<0.05$.

${ }^{\mathrm{v}} P P F D=$ photosynthetic photon flux density.

Table 4. Contrasts of blueberry bush tissues above the top $(51 \mathrm{~cm})$ of two grow tubes-white translucent (TR) and beige opaque (OP), and under ambient conditions [no tube (NT)] at the end of the establishment year. ${ }^{\mathrm{z}}$

\begin{tabular}{|c|c|c|c|c|c|c|c|}
\hline \multirow[b]{2}{*}{ Variable } & \multicolumn{3}{|c|}{ Treatment means } & \multicolumn{4}{|c|}{ Contrast $P$ values } \\
\hline & NT & TR & OP & NT vs. tube & NT vs. TR & NT vs. OP & OP vs. TR \\
\hline Plant height (cm) & $37.0(4.04)$ & $87.7(5.81)$ & $77.3(8.41)$ & 0.001 & 0.001 & 0.004 & $\mathrm{NS}^{\mathrm{y}}$ \\
\hline Leaf area $\left(\mathrm{cm}^{2}\right)$ & $1768(226.2)$ & $5651(926.4)$ & $4525(911.1)$ & 0.012 & 0.011 & 0.043 & NS \\
\hline Fruiting bud number & $60.3(9.74)$ & $92.7(17.47)$ & $131.0(23.90)$ & NS & NS & 0.032 & NS \\
\hline Whip number ${ }^{x}$ & $4.0(1.15)$ & $10.3(1.76)$ & $5.3(0.33)$ & 0.044 & 0.011 & 0.473 & 0.028 \\
\hline Whip diameter (mm) & $3.3(0.38)$ & $4.6(0.02)$ & $4.5(0.30)$ & 0.01 & 0.017 & 0.021 & NS \\
\hline One-year-old wood dry matter (g) & $7.3(1.20)$ & $48.3(7.67)$ & $35.0(7.55)$ & 0.001 & 0.0021 & 0.0032 & NS \\
\hline Leaf dry matter (g) & $22.3(3.18)$ & $63.7(8.95)$ & $50.0(10.15)$ & 0.013 & 0.011 & NS & NS \\
\hline Specific leaf area $\left(\mathrm{cm}^{2} \cdot \mathrm{g}^{-1}\right)$ & $79.6(1.54)$ & $88.0(2.67)$ & $90.7(1.82)$ & 0.008 & 0.027 & 0.009 & NS \\
\hline Dry matter above $51 \mathrm{~cm}(\mathrm{~g})$ & $29.7(4.33)$ & $112.0(16.56)$ & $85.0(17.69)$ & 0.008 & 0.006 & 0.033 & NS \\
\hline
\end{tabular}

${ }^{\mathrm{z}}$ Numbers in parentheses are SES of the mean.

${ }_{\mathrm{N}}^{\mathrm{NS}}=$ Nonsignificant at $P<0.05$.

${ }^{x}$ The number of whips that elongated to greater than $51 \mathrm{~cm}$.

Table 5. Contrasts of growth indicators for blueberry bushes in their entirety at the end of the establishment year, having grown in one of two grow tubes: white translucent (TR) and beige opaque (OP), or at ambient conditions [no tube (NT)]. ${ }^{\mathrm{r}}$

\begin{tabular}{|c|c|c|c|c|c|c|c|}
\hline \multirow[b]{2}{*}{ Variable } & \multicolumn{3}{|c|}{ Treatment Means } & \multicolumn{4}{|c|}{ Contrast $P$ values } \\
\hline & NT & TR & OP & NT vs. tube & NT vs. TR & NT vs. OP & OP vs. TR \\
\hline Total plant height $(\mathrm{cm})$ & $88.0(4.04)$ & $138.7(5.81)$ & $128.3(8.41)$ & 0.011 & 0.001 & 0.004 & $\mathrm{NS}^{\mathrm{y}}$ \\
\hline Plane area of canopy $\left(\mathrm{cm}^{2}\right)^{x}$ & $4607(474.4)$ & $2481(361.4)$ & $2152(284.1)$ & 0.0027 & 0.007 & 0.004 & NS \\
\hline Rating $^{\mathrm{w}}$ & $2.3(0.17)$ & $5.0(0)$ & $4.8(0.14)$ & $<0.001$ & $<0.001$ & $<0.001$ & NS \\
\hline Total leaf area $\left(\mathrm{cm}^{2}\right)$ & $6013(1102.1)$ & $8166(1134.2)$ & $5733(1037.6)$ & NS & NS & NS & NS \\
\hline Total fruiting bud number & $119.3(11.35)$ & $101.0(17.44)$ & $136.3(24.55)$ & NS & NS & NS & NS \\
\hline Total one-year-old wood dry matter (g) & $78.0(13.65)$ & $120.0(19.55)$ & $72.3(13.86)$ & NS & NS & NS & NS \\
\hline Total leaf dry matter (g) & $73.3(13.38)$ & $86.0(10.00)$ & $57.0(11.14)$ & NS & NS & NS & NS \\
\hline Specific leaf area $\left(\mathrm{cm}^{2} \cdot \mathrm{g}^{-1}\right)$ & $81.9(0.66)$ & $94.4(2.63)$ & $101.5(3.01)$ & 0.001 & 0.009 & 0.001 & NS \\
\hline Above-ground:below-ground ${ }^{\mathrm{v}}$ & $1.15(0.053)$ & $1.42(0.087)$ & $1.37(0.100)$ & NS & NS & NS & NS \\
\hline Total dry matter $(\mathrm{g})$ & $263.0(42.25)$ & $328.0(35.51)$ & $247.7(50.93)$ & NS & NS & NS & NS \\
\hline
\end{tabular}

${ }^{\mathrm{z}}$ Numbers in parentheses are SES of the mean.

$\mathrm{y}_{\mathrm{NS}}=$ Nonsignificant at $P<0.05$.

${ }^{\mathrm{x}}$ The plane area projected by the canopy was estimated by measuring in orthogonal directions the maximum diameter of the canopy.

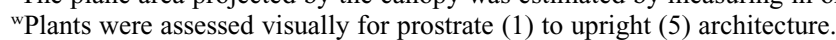

${ }^{\mathrm{v}}$ Above-ground:below-ground dry matter $(\mathrm{DM})=[($ above-ground DM, excluding leaves $) /($ root + crown $) \mathrm{DM}]$.

buds in highbush blueberry cultivars, the quantity of solar radiation required is not known, although in one study, fruiting bud number increased with the length of time shoots were exposed to short daylength (Bañados and Strik, 2006). The more prostrate growth of the NT plants (Table 5) may have increased fruiting bud development because vigorously growing upright shoots produce fewer fruiting buds than slower growing, more horizontal shoots (Strik, personal observation).

The mentioned data indicate that surface and near-surface temperatures had an interactive effect with $P P F D$ on growth of the lower part of the bush. Because temperature is coupled with solar radiation, it is not trivial to consider independently the effects of solar radiation and temperature on growth inside the tube. Similar difficulty is encountered in determining causal associations between tube microclimate across the season and the integrated plant response at the end of the establishment year. When the shoots emerged from the tops of the grow tubes, the upper tissues were exposed to ambient conditions, whereas the lower portions of the plant were in a warm, dark environment for the remainder of the establishment year.

Above the top of the tube, plant growth differed dramatically between NT and the two tubes, which were similar to one another in all respects except whip elongation (Table 4 ), where significantly more whips grew taller than $51 \mathrm{~cm}$ in TR. Above the top of the tube, TR and OP plants grew 40 to $50 \mathrm{~cm}$ taller than NT plants, had five to six times more DM than NT in 1-year-old wood, and two to three times more leaf area than NT. However, the leaves remained thinner than those of non-tubed plants, suggesting that the newly formed leaves of the tubed plants did not shift from shade- to sun-acclimated morphology. Above $51 \mathrm{~cm}$, the tubed plants had a higher whip diameter than the non-tubed plants. Above the top of the tube, TR and OP plants also were more upright than NT plants based on canopy diameter and the prostrate/ 
upright rating. In Fagus and Acer saplings, with an abrupt change from low to high solar radiation, tree response included an increase in canopy diameter and height, and strong stem reorientation toward the vertical (Collet et al., 2011).

Above $51 \mathrm{~cm}$, NT plants produced only $26 \%$ (OP) to $35 \%$ (TR) of the total DM of tubed plants, indicating more upright, vigorous growth of tubed plants relative to the more prostrate growth of NT plants. In western red cedar (Thuja plicata) seedlings, shading the lower portion of the plant resulted in increased net photosynthesis, stomatal conductance, and transpiration in the fully illuminated upper portion of the plant (Pepin et al., 2002). In Nothofagus nitida seedlings, acclimation to high solar radiation resulted in a significant increase in the light saturation point of photosynthesis in the new leaves without a corresponding increase in dark respiration (Coopman et al., 2008). The heated lower stems $\left(\mathrm{T}_{\text {stem }}, \mathrm{T}_{\mathrm{sm}}\right)$ in our grow tubes may have induced lower phloem and xylem resistance. If so, there also was the potential for an increase in carbohydrate transport from the fully illuminated portion of bush to the crown and roots. However, because a majority of the leaves produced by TR and OP plants was above the tube, on a whole plant basis, the tubes may have had little impact on whole plant transpiration. Much of the above-tube growth was associated with above-ground and near-surface temperatures inside the tube (data not shown).

Considering the plant in its entirety-the sum of the tissues above and below the top of the tube (Table 5) - at the end of the establishment year, there were no differences among treatments in all measures of growth and reproductive development (i.e., number of fruit buds) except plant height, vertical orientation, and leaf thickness. For the whole plant, those in the two tubes did not differ from one another. By contrast, Strik et al. (2014) found that the influence of tubes on the number of fruiting buds depended on tube type and blueberry cultivar. They also reported reduced root and crown mass and a higher above-ground to below-ground dry mass ratio in tubed plants compared with NT. In the present study, the greater growth and associated source strength of tubed plants once they passed the top of the tube may have led to compensation in crown and root mass (sink). The absence of differences among treatments in total leaf area was the result of the vast differences in leaf area for the segment of the bushes above the tubes. With respect to vertical orientation, upright shoots grow more vigorously and branch less than prostrate shoots (Strik, personal observation; Lovisolo and Schubert, 2000). Kawamura and Takeda (2002) found that in a shadeadapted Vaccinium species ( $V$. bracteatum Thunb.), increases in incident solar radiation resulting from overstory canopy gaps led to increased elevation angle of the leader shoots. That the NT plants were more prostrate reflects the natural growth habit of the bush, whereas the lower $51 \mathrm{~cm}$ of the tubed plants were constrained to a cross-sectional area of $314 \mathrm{~cm}^{2}$. There may have been physical carryover of that restrictive effect in addition to radiation-mediated vertical orientation of previously shaded shoots.

Grow tubes can alter significantly the microclimate of the aerial and substrate portions of blueberry plants. Differences in microclimate measured in the present study altered the architecture of blueberry plants but caused few differences in total plant size and DM at the end of the establishment year. The bushes grown under ambient conditions or in grow tubes distributed tissues differently but produced the same above-ground to below-ground ratio, total dry mass, leaf area, number of fruiting buds, dry mass in crown and roots, and dry mass in 1- and 2-year-old wood. Tubed plants showed remarkable compensatory growth in the canopy that developed above the tube. Tubes induced taller, more upright plants with more top growth and reproductive structures than those grown under ambient conditions. In terms of application, growers will need to consider a cost: benefit of the tubes. As physical barriers, the tubes protect young bushes from herbicide applications, early-season herbivory, and, for the lower part of the bush, wind damage. However, the tubes induced more upright growth, which is contrary to the bush's natural growth habit.

\section{Literature Cited}

Abbott, J.D. and R.E. Gough. 1987. Seasonal development of highbush blueberry roots under sawdust mulch. J. Amer. Soc. Hort. Sci. 112:60-62.

Baird, M.H.I. and B.A. Legree. 1994. Natural convective heat transfer from open vertical tubes. Can. J. Chem. Eng. 72:755-758.

Bañados, P. and B. Strik. 2006. Manipulation of the annual growth cycle of blueberry using photoperiod. Acta Hort. 715:65-71.

Bellot, J., J.M. Ortiz de Urbina, A. Bonet, and J.R. Sánchez. 2002. The effects of treeshelters on the growth of Quercus coccifera L. seedlings in a semiarid environment. Forestry 75:89-106.

Bergez, J.-E. and C. Dupraz. 1997. Transpiration rate of Prunus avium L. seedlings inside an unventilated shelter. For. Ecol. Mgt. 97:255-264.

Bergez, J.-E. and C. Dupraz. 2000. Effect of ventilation on growth of Prunus avium seedlings grown in treeshelters. Agr. For. Meteorol. 104:199-204.

Bryla, D.R. and B.C. Strik. 2007. Effects of cultivar and plant spacing on the seasonal water requirements of highbush blueberry. J. Amer. Soc. Hort. Sci. 132:270-277.

Bryla, D.R., B. Yorgey, and A.D. Shireman. 2009 Irrigation management effects on yield and fruit quality of highbush blueberry. Acta Hort. 810:649-656.

Burger, D.W., P. Svihra, and R. Harris. 1992. Treeshelter use in producing container-grown trees. HortScience 27:30-32.

Collet, C., M. Fournier, F. Ningre, A.P.-I. Houzandji, and T. Constant. 2011. Growth and posture control strategies in Fagus sylvatica and Acer pseudoplantus saplings in response to canopy disturbance. Ann. Bot. (Lond.) 107:1345-1353.

Coopman, R.E., M. Reyes-Diáz, V.F. Briceños, J. Corcuera, H.M. Cabrera, and L.A. Bravo. 2008. Changes during early development in photosynthetic light acclimation capacity explain the shade to sun transition in Northofagus nitida Tree Physiol. 28:1561-1571

Coutand, C., C. Dupraz, G. Jaouen, S. Ploquin, and B. Adam. 2008. Mechanical stimuli regulate the allocation of biomass in trees: Demonstration with young Prunus avium trees. Ann. Bot. (Lond.) 101:1421-1432.

Due, G. 1990. The use of polypropylene shelters in grapevine establishment - A preliminary trial. Aust. Grapegrower Winemaker. June:29-33.

Dupraz, C. and J.-E. Bergez. 1999. Carbon dioxide limitation of the photosynthesis of Prunus avium L. seedlings inside an unventilated treeshelter. For. Ecol. Mgt. 119:89-97.

Gerhold, H.D. 1999. Species differ in response to tree shelters. J. Aboric. 25:76-80.

Grace, J. 1983. Plant-atmosphere relationships. Chapman and Hall, New York, NY.

Hall, I.V., L.E. Aalders, N.L. Nickerson, and S.P. Vander Kloet. 1979. The biological flora of Canada. 1. Vaccinium angustifolium Ait., sweet lowbush blueberry. Can. Field Nat. 93:415430.

Hall, T.W. and W.F. Mahaffee. 2001. Impact of vine shelter use on development of grape powdery mildew. Amer. J. Enol. Viticult. 52:204-209.

Hancock, J.F., K. Haghighi, S.L. Krebs, J.A. Flore, and A.D. Draper. 1992. Photosynthetic heat stability in highbush blueberries and the possibility of genetic improvement. HortScience 27:1111-1112.

Jones, H.G. 2014. Plants and microclimate. $3^{\text {rd }} \mathrm{Ed}$. Cambridge University Press, Cambridge, UK.

Julian, J., B. Strik, and W. Yang. 2011. Blueberry economics: The costs of establishing and producing blueberries in the Willamette Valley, Oregon. Oregon State Univ. Pub. AEB 0022. $<\mathrm{http}$ ://arec.oregonstate.edu/oaeb/files/pdf/ AEB0022.pdf>.

Kawamura, K. and H. Takeda. 2002. Light environment and crown architecture of two temperate Vaccinium species: Inherent growth rules versus degree of plasticity in light response. Can. J. Bot. 80:1063-1077.

Kim, S.J., D.J. Yu, T.-C. Kim, and H.J. Lee. 2011 Growth and photosynthetic characteristics of blueberry (Vaccinium corymbosum cv. Bluecrop) under various shade levels. Sci. Hort. 129:486-492.

Kjelgren, R. 1994. Growth and water relations of Kentucky coffee tree in protective shelters during establishment. HortScience 29:777780 .

Kjelgren, R. and L.A. Rupp. 1997. Establishment in treeshelters I: Shelters reduce growth, water use, and hardiness, but not drought avoidance. HortScience 32:1281-1283.

Kjelgren, R., D.T. Montague, and L.A. Rupp. 1997. Establishment of treeshelters. II: Effect of shelter color on gas exchange and hardiness. HortScience 32:1284-1287.

Larco, H., B.C. Strik, D.R. Bryla, and D.M. Sullivan. 2013. Mulch and fertilizer management practices for organic production of highbush blueberry: I. Plant growth and allocation of biomass during establishment. HortScience 48:1250-1261.

Lobos, G.A., J.B. Retamales, J.F. Hancock, J.A. Flore, N. Cobo, and A. del Pozo. 2012. Spectral irradiance, gas exchange characteristics and leaf traits of Vaccinium corymbosum L. 'Elliott' grown under photo-selective nets. Environ. Exp. Bot. 75:142-149.

Lobos, G.A., J.B. Retamales, J.F. Hancock, J.A. Flore, S. Romero-Bravo, and A. del Pozo. 2013. Productivity and fruit quality of $\mathrm{Vacci}-$ nium corymbosum L. 'Elliott' under photoselective shading nets. Sci. Hort. 153:143-149. 
Lovisolo, C. and A. Schubert. 2000. Downward shoot positioning affects water transport in field-grown grapevines. Vitis 39:49-53.

Mayhead, G.J. and I.R. Boothman. 1997. The effect of treeshelter height on the early growth of sessile oak [Quercus petraea (Matt.) Liebl.]. Forestry 70:151-155.

Moon, J.W., J.A. Flore, and J.F. Hancock, Jr. 1987. A comparison of carbon and water vapor gas exchange characteristics between a diploid and highbush blueberry. J. Amer. Hort. Sci. 112:134-138.

Munnell, J.A. 2003. Determining the microenvironmental factors of grow tubes that affect grapevine (Vitis vinifera) growth and development. MS thesis, Wash. State Univ., Pullman, WA.

Murray, F.W. 1967. On the computation of saturation vapour pressure. J. Appl. Meteorol. 6:203204.

Nobel, P.S. 1999. Physiochemical and environmental plant physiology. 2nd Ed. Academic Press, New York, NY.

Ogden, A.B. and M.W. van Iersel. 2009. Southern highbush blueberry production in high tunnels: Temperatures, development, yield, and fruit quality during the establishment years. HortScience 44:1850-1856.

Pepin, S., N.J. Livingston, and D. Whitehead. 2002. Responses of transpiration and photosynthesis to reversible changes in photosynthetic foliage area in western red cedar (Thuja plicata) seedlings. Tree Physiol. 22:363-371.

Retamales, J.B. and J.F. Hancock. 2012. Blueberries. CABI, Cambridge, MA.

Rho, H., D.J. Yu, S.J. Kim, and H.J. Lee. 2012. Limitation factors for photosynthesis in 'Bluecrop' highbush blueberry (Vaccinium corymbosum) leaves in response to moderate water stress. J. Plant Biol. 55:450-457.

Scuderi, D., F. Giuffrida, S. Toscano, and D. Romano. 2012. Growth, physiological response, and quality characteristics of weeping fig in response to shading levels and climatic conditions. HortScience 11:1586-1592.

Sharew, H. and A. Hairston-Strang. 2005. A comparison of seedling growth and light transmission among tree shelters. North. J. Appl. For. 22:102-110.

Sharpe, W.E., B.R. Swistock, K.A. Mecum, and M.C. Demchik. 1999. Greenhouse and field growth of northern red oak seedlings inside different types of treeshelters. J. Arbor. 25:249-257.

Strik, B., C. Brun, M. Ahmedullah, A. Antonelli, L. Askham, D. Barney, P. Bristow, G. Fisher, J. Hart, D. Havens, R. Ingham, D. Kaufman, R. Penhallegon, J. Pscheidt, B. Scheer, C. Shanks, and R. William. 1993. Highbush blueberry production. Ore. State. Univ. Ext. Serv. Pub. PNW 215.
Strik, B.C., G. Buller, and J.M. Tarara. 2014 Grow tubes reduce root and crown growth but not early production during establishment of highbush blueberry. HortScience 49:581588.

Strik, B.C., J.R. Clark, C.E. Finn, and G. Buller. 2012. Management of primocane-fruiting blackberry-Impacts on yield, fruiting season, and cane architecture. HortScience 47:593598.

Swartz, H.J., S.E. Gray, L.W. Douglass, E. Durner, C.S. Walsh, and G.J. Galletta. 1984. The effect of a divided canopy trellis design on thornless blackberry. HortScience 19:533-535.

Tarara, J.M., B. Chaves, and B.C. Strik. 2013. Above- and below-ground microclimate of grow tubes in an organic mulch-incorporated, raised bed system for blueberry. HortScience 48:1363-1369.

Tarara, J.M. and J.M. Ham. 1999. Measuring sensible heat flux in plastic mulch culture with aerodynamic conductance sensors. Agr. For. Meteorol. 95:1-13.

Tuley, G. 1983. Shelters improve the growth of young trees in the forest. Qrtly. J. For. 77:77-87.

Yáñez, P., J.B. Retamales, G.A. Lobos, and A. del Pozo. 2009. Light environment within mature rabbiteye blueberry canopies influences flower bud formation. Acta Hort. 810:471473. 